\title{
The Impact of Academic and Organizational Supervision on the Teacher Performances in the State High School in Ogan Komering Ulu Regency
}

\author{
Budi Taryono $^{1 *}$, Nur Ahyani², Dessy Wardiah ${ }^{2}$
}

\author{
${ }^{I}$ SMAN OKU \\ ${ }^{2}$ Universitas PGRI Palembang \\ *Corresponding author. Email: budi.tar71@gmail.com
}

\begin{abstract}
The performance of the teacher is the consequence, performance and execution of the duties of a teacher as a teacher and trainer for its pupils. The teacher performance is the performance of the teacher. Therefore, the problem of teacher performance is not optimal because the teacher's commitment to their duties has not been carried out properly. In order to tie the performance of principal teachers, it is necessary to maximize academic supervision and create a good organizational culture. Based on this, this research's problem is whether academic supervision and organizational culture affect teacher performance in SMA Negeri Ogan Komering Ulu Regency. The goal of this analysis is to assess the effects on teacher success in the SMA in Negeri Ogan Komering Ulu Regency of academic and organizational management. This research belongs to the type of correlational research. Samples of respondents to be used in the study at SMAN 1 OKU, SMAN 4 OKU and SMAN 5 OKU totaled 86 people. Cluster sampling is the method used in this analysis. Closed questionnaires, interviews, documentation and findings were included in the data collection methods used in this trial. Multiple regression analysis for data analysis. The findings have shown that academic supervision in SMA Negeri Ogan Komering Ulu Regency has an effect on teacher success, The teaching success at SMA Negeri Ogan Komering Ulu Regency was affected by organizational culture, and Academic Supervision and organizational culture had a together on teacher performance in SMA Negeri Ogan Komering Ulu Regency.
\end{abstract}

Keywords: Teacher Performance, Academic Supervision, Organizational Culture

\section{INTRODUCTION}

There are teachers in SMA Negeri Ogan Komering Ulu Regency who show a terrible culture and performance. Teachers still have not been disciplined in their work. It can be seen on the assigned assignment, they are not enthusiastic in carrying out their duties, at work, the teacher shows less attention to the implementation of tasks.

Factors affecting teacher performance include teacher education level, supervision, good culture, facilities and infrastructure, teachers' physical and mental condition, school principals' leadership style, welfare assurance, school principals' managerial ability, and others.

The success in school education is determined largely by the attention of the principal on the teaching personnel of schools. The main element is one of the elements of education that contributes to teacher success. The director is responsible for implementing training programs, school management, supporting other educational staff as well as the use and repair of equipment and facilities. In line with the increasingly complicated taskes of the leaders of schools, which need flexible and efficient management assistance, this becomes more importantThe principal is to be able to implement innovative education systems, to maintain a favorable school environment, and to increase the success of the school's staff and to lead teachers in the course of learning.

The principal is always worked with his subordinate teachers, monitoring and assessing their daily activities. The low performance of teachers will affect the implementation of tasks which will also affect educational goals. Low teacher performance must identify the cause. Various factors influence a teacher's teaching performance. In such conditions, the principal plays an important role because it can provide a climate that supports a passionate teacher. With managerial skills possessed, school principals, build and improve positive 
teacher performance. Furthermore, the guidance of the principal plays a key role in optimizing teaching efficiency. Academic supervision helps teachers take self-direction and learn to solve the problems they face independently, and accordingly encourages them to activities to create situations in which students can learn more effectively.

The state of teachers in the Ogan Komering Ulu Senior High School District indicates that those teachers have done maximal work as teachers, teachers and trainers in their roles and functions. But some teachers do have poor results, but in general they don't impair teacher performance. The extent of teacher success can be seen from the sense of duty in fulfilling their mandate, their career and their sense of moral responsibility. This is often compounded by a feeling of guilt for preparing all the facilities before the learning process is carried out. In accordance with observations and interviews in the field, teachers whose performance is maximal because they feel satisfied in their work and frequent communication are supervised by the principal, while teachers whose performance is less than optimal is caused by internal factors and communication relationships with the principal.

According to Sunarsi [1], success is "the product of an individual doing his/her job in quality and quantity with accountability". Siagian [2] defines the notion of performance as "a person's total ability to work in such a way as to achieve goals that work optimally and various goals that have been created with sacrifices that are smaller ratios compared to the results achieved."

The results of the research by Asran [3] concluded: (1) the principal's management style has a major impact on teacher success with 50.60 per cent contribution, (2) the corporate culture has an important impact on teacher performance with 46.4 per cent contribution, and (3) the leadership style. Together the key and corporate culture have an important impact on teacher success at 79.3 percent; other aspects outside of study influence the remaining 20.7 percent of teacher performance.

The findings of the study by Oktaviani [4] indicate that: (1) the performance of Prabumulih City Junior School teachers has positive and significant consequences for academic supervision; (2) that the management of the principal has a positive and significant impact on SMP Negeri-Prabumulih City teachers' performance, and (3) the combined constructive and important impact on the achievement of teachers at the Prabumulih City Junior High Schcols has on the academic oversight of supervisors and the primary executive leadership. The link between the above research and this research is the similarity of the variables studied, namely Academic Supervision and Teacher Performance.
The research by Arifin [5] findings: (1) the variables of corporate culture, leadership and inspiration of teachers on the success of the educators at the SMP N 2 Paciran are simultaneously significantly affectable; (2) The workplace culture has a substantial impact on the success of teachers. The principal's leadership predictor has little direct impact on the success of the instructor. The incentive component of the teacher affects the teacher's success significantly, and (3) Organizational culture has a direct impact on instructor success of $29.7 \%$. Meanwhile, instructor success has a direct motivational influence of $20 \%$. The indirect impact on instructor success of organizational culture was $15.2 \%$. Meanwhile, the indirect effect of motivation on the performance of educators is $15.2 \%$. The link between the above research and this research is the similarity of the variables studied, namely Organizational Culture and Teacher Performance.

Research by Yusuf [6] results: 1) Academic supervision of school principals that have been carried out in Public SDs throughout Cibadak District is in the good category; 2) The organizational culture found in Public Elementary Schools in Cibadak Subdistrict is in the very good category; 3) The teaching performance of teachers in SD Negeri in Cibadak District is in the very good category; 4) Principal academic supervision has positive and significant implications of the performance of teachers in the teaching sector, as well as a strong impact, and 5) Corporate culture has a positive and significant impact on teachers and its influence is strongly classified as a teacher's education.

In the above problems, we need to find solutions to other factors because they will impact schools' education outcomes, especially in Ogan Komering Ulu Regency. Therefore, further research is needed on "The influence of academic supervision and organizational culture on teacher performance in SMA Negeri Ogan Komering Ulu Regency."

\section{METHODS}

This research was conducted at SMA Negeri Ogan Komering Ulu Regency, which has 17 Public Senior High Schools located in 13 Districts. Each district has different conditions. This research was conducted in East Baturaja District, which has 3 public schools and this research was carried out in October-November 2020. A quantitative methodology is used in this analysis, as the results collected are presented in numbers and analysed according to statistics. According to Sugiono [7] a quantitative method is used by a random sampling procedure to test a certain population or specimen. Data collection using tools of mathematical analysis to evaluate the range of hypotheses.

This study's population were civil servant teachers or permanent teachers and non-civil-servant teachers or 
non-permanent teachers at SMA Negeri Ogan Komering Ulu Regency. According to their functional position and educational qualifications, this population has the same characteristics because teachers at SMA Negeri Ogan Komering Ulu Regency are generally the same, namely undergraduate. The population details are as follows:

Table 1. Teacher Population at SMA Negeri Ogan Komering Ulu Regency

\begin{tabular}{|c|l|c|}
\hline No & School name & $\begin{array}{c}\text { Number of Teachers } \\
\text { (Population) }\end{array}$ \\
\hline 1 & SMAN 1 OKU & 67 \\
\hline 2 & SMAN 4 OKU & 45 \\
\hline 3 & SMAN 5 OKU & 51 \\
\hline & TOTAL & $\mathbf{1 6 3}$ \\
\hline
\end{tabular}

Source:MKKS SMA OKU Regency

This research was made up of 3 high schools, a total of 163 teachers, located in Ogan Kommering Ulu Regency. This sample is part of teachers at the state secondary schools in the district of Ogan Komering Ulu. Cluster sampling is the sampling technique in this analysis (area sampling). The methodology for cluster sampling is used to decide if the target to be analyzed or the source of information is complete [7]. This cluster sampling technique is used through one stage, namely determining individual samples. Determination of Individual Samples At this stage, the individual sample determination stage is carried out. The technique of determining the sample size used is based on Isaac and Michael, quoted by Sugiono [7]. Sampling confidence in the population is $90 \%$ or an error rate of $10 \%$, using the Issac and Michael sampling table to achieve a sample size of 86 individuals. This study uses interview data collection techniques, questionnaires/questionnaires, observations/observations, and documentation.

For the research results to be declared valid, the research instrument in the form of a questionnaire should be tested First for its authenticity and trustworthiness. To know when an instrument is valid and reliable, it must go through instrument testing. The trial was carried out on groups of people (samples) from the target population, but did not include samples that would fill out the real research instruments. The population in this study amounted to 163 teachers, while those included in the study sample were 86 teachers, so that the instrument testing was carried out on 20 teachers who were included in the population, but not included as the sample.

Before the analysis is carried out, the analysis requirements are also conducted for predictive purposes and hypothesis testing. Three conditions must be met before carrying out regression analysis. There are 1) Normality Test, 2) Homogeneity Test, and 3) Linearity Test. Analysis of the data in this study using quantitative methods. This method is expected to get more accurate measurement results about the respondents' responses. The numerical data can be processed using statistical methods. The research data will be tested through several stages, such as a multiple Regression Test, T-Test, FTest, and the Coefficient of Determination. They were testing each data analysis using SPSS version 22.0.

\section{RESULTS AND DISCUSSION}

Data from the distribution of questionnaires to respondents is described in tabulated form regarding the characteristics of the respondents consisting of gender, latest education, and level of education. The following shows the characteristics of respondents as many as 86 teachers from SMA Negeri 1 OKU, SMA Negeri 4 OKU and SMA Negeri 5 OKU which are located in Ogan Komering Ulu (OKU) District. It can be explained that the research respondents were dominated by women, namely $79 \%$, while men were $21 \%$. It can be explained that the majority of respondents have an undergraduate education, namely $79 \%, 16.3 \%$ of respondents have a S2 education, $4.7 \%$ of respondents have a D3 education and no respondent has a doctoral education.

Based on the Academic Supervision variable's descriptive statistical data, The average value can be seen reaching 135.56 , the regular default is 6.89 , the overall value is 11.658 , the minimum is 121 , and the highest value is 150 . At the same time, Organizational Culture shows that the average value reaches 134, 90, the standard deviation is 7.35 with a total value of 11,601 with a value of minimum 120 with a value of maximum 150. The average value is 135.80 for teachers results, the standard deviation is 7.73 , with a total value of 11,679 with the minimum value is 120 . The maximum value is 150. To explain more clearly, you can see the frequency distribution on each variable.

The Academic Supervision variable's frequency distribution $\left(\mathrm{X}_{1}\right)$ explains the number of respondents who answered based on the total score for each respondent on the Academic Supervision variable $\left(\mathrm{X}_{1}\right)$. In the Academic Supervision variable questionnaire $\left(\mathrm{X}_{1}\right)$ there were 30 items and were answered by 86 respondents while the 
answers of respondents who answered with the smallest number of values were 121 , namely $1.2 \%$ and those who answered with the greatest value of 150 were also $1.2 \%$ of respondents' answers were dominated by 135 values, namely by $12.8 \%$

This means that in general the respondents want regular Academic Supervision to be carried out and some respondents want it to be improved because there are still respondents who answer with the lowest score.

The frequency distribution of the Organizational Culture variable $\left(\mathrm{X}_{2}\right)$ explains the number of respondents who answered based on the total score for each respondent on the Organizational Culture variable $\left(\mathrm{X}_{2}\right)$. In the Organizational Culture variable questionnaire $\left(\mathrm{X}_{2}\right)$ there were 30 items and were answered by 86 respondents while the answers of respondents who answered with the smallest number of values were 120 , namely $2.3 \%$ and those who answered with the greatest value of 150 were also $1.2 \%$ of respondents' answers were dominated by 135 values, namely by $8.1 \%$. This means that in general, respondents want Organizational Culture (X2) to be maintained. Some respondents want it to be improved because there are still respondents who answer with the lowest score.

The frequency distribution of the Teacher Performance variable (Y) explains the number of respondents who answered based on the total score for each respondent on the Teacher Performance variable (Y). Thirty items were answered by 86 respondents. In general, the respondents have a good performance, but there are still some respondents whose performance needs to be improved because there are still respondents who answer with the lowest score.

The results of testing the data analysis requirements for normality test data on the variables of Academic Supervision, Organizational Culture, and teacher performance usually are distributed and can be continued with regression tests. The homogeneity test results demonstrate that the same or homogeneous data comes from the two independent and one dependent variables. The linearity test results show that there is a linear relationship with the teacher performance variables between the academic supervision variables and the organizational culture variables.

The linear association between two or more independent (Advanced/ $\mathrm{X}_{1}$ and Organizational Culture/ $\mathrm{X}_{2}$ ) and the dependent (teacher performance/Y) variable is the study of multiple linear regressions. In this analysis, the orientation of the relation between the independent variable and the dependent variable will be determined. Each independent variable has a positive or negative relationship and predicts its dependent variable value by increasing or decreasing the value of the independent variable. Table 2 provides the various outcomes of linear regression tests with SPSS 22.0.

Table 2. Multiple Correlation Linear Regression Test Results

Coefficients

\begin{tabular}{|c|c|c|c|c|c|}
\hline \multirow[b]{2}{*}{ Model } & \multicolumn{2}{|c|}{$\begin{array}{l}\text { Unstandardized } \\
\text { Coefficients }\end{array}$} & \multirow{2}{*}{$\begin{array}{c}\text { Standardized } \\
\text { Coefficients }\end{array}$} & \multirow[b]{2}{*}{$\mathrm{t}$} & \multirow[b]{2}{*}{ Sig. } \\
\hline & B & Std. Error & & & \\
\hline (Constant) & 42.160 & 9.956 & & 4.235 & .000 \\
\hline $\begin{array}{l}\text { Academic } \\
\text { Supervision }\end{array}$ & .241 & .090 & .270 & 2.678 & .009 \\
\hline $\begin{array}{l}\text { Organizational } \\
\text { culture }\end{array}$ & .459 & .089 & .519 & 5.140 & .000 \\
\hline
\end{tabular}

a. Dependent Variable: Teacher Performance

On the basis of multiple linear regression findings analyzed in the instructor success variables Academic Supervisory $\left(\mathrm{X}_{1}\right)$ and Organizational Culture $\left(\mathrm{X}_{2}\right)$, it can be defined as follows:

$$
Y=42.160+0.241 X_{1}+0.459 X_{2}
$$

The following can be explained based on the aforementioned multiple linear regression equation:

1) The constant coefficient of 42.160 means that if Academic Supervision $\left(\mathrm{X}_{1}\right)$ and Organizational Culture $\left(\mathrm{X}_{2}\right)$ are 0 or constant, then the teacher's performance $(\mathrm{Y})$ is 42.160 
2) The coefficient value of the Academic Supervision $\left(\mathrm{X}_{1}\right)$ variable is 0.241 , meaning that if Academic Supervision $\left(\mathrm{X}_{1}\right)$ increases by 1 unit score, the teacher's performance (Y) will increase by 0.241 , assuming the Organizational Culture coefficient is 0 or constant.

3) The value of the vector organizational culture $\left(X_{2}\right)$ is 0.459 , which means that if organic culture $\left(\mathrm{X}_{2}\right)$ increases by 1 unit score, the output of the instructor (Y) would increase by 0.459 , assuming that the coefficient of academic oversight is 0 or stable.
This measure determines whether or not the independent variables (academic monitoring and organizational culture) affect the dependent variable at the same time (teacher performance). If $\operatorname{sig}>\alpha(0.05)$, the variables of instructor success are not influenced by academic monitoring $\left(\mathrm{X}_{1}\right)$ and organizational culture $\left(\mathrm{X}_{2}\right)$ on $(\mathrm{Y})$. If $\operatorname{sig}<\alpha(0.05)$, so there is an effect on instructor success between the Academic Supervision $\left(\mathrm{X}_{1}\right)$ on $(\mathrm{Y})$. Table 3 below shows the effects of the $\mathrm{F}$ test (simultaneous hypothesis) for this analysis.

Table 3. F Test Results (Simultaneous Hypothesis)

ANOVA $^{\mathrm{b}}$

\begin{tabular}{|c|c|c|c|c|c|}
\hline \multicolumn{1}{|c|}{ Model } & Sum of Squares & df & Mean Square & F & Sig. \\
\hline $1 \quad$ Regression & 5806.318 & 2 & 2903.159 & 46.519 & $.000^{\mathrm{a}}$ \\
Residual & 5179.821 & 83 & 62.407 & & \\
& 10986.140 & 85 & & & \\
\hline & Total & & & & \\
\hline
\end{tabular}

a. Predictors: (Constant), Organizational culture, Academic Supervision

b. Dependent Variable: Teacher Performance

Simultaneous testing shows that the value of Fcount is 46.519 and Fsig is 0.000, while the Ftable value for $\mathrm{dk}$ $=\mathrm{n}-2-1=86-2-1=83$ is 3.11 (F table attached). The value of F-count (46.519)> F-table (3.11) and the value of F-sig $(0.000)<\alpha(0.05)$, Ho is then refused and Ha admitted. It can be clarified that the success of teachers in the Ogan Komering Ulu Regency Senior High School is influenced by academic supervision and organizational culture. More specifics can be found in the appendix in the results of the F test (simultaneous hypothesis).

The effect of a variable Academic Supervision $\left(X_{1}\right)$ or teacher success variable $\left(\mathrm{X}_{2}\right)$ of organisation's culture (PC) is assessed or tested partially by looking at its value for current teachers' productivities. The effect of variable $\mathrm{Y}$ is assessed or tested.

Table 4. T-test results (partial hypothesis)

Coefficients $^{\mathrm{a}}$

\begin{tabular}{|c|c|c|c|c|c|}
\hline \multirow[b]{2}{*}{ Model } & \multicolumn{2}{|c|}{ Unstandardized Coefficients } & \multirow{2}{*}{$\begin{array}{c}\text { Standardized } \\
\text { Coefficients }\end{array}$} & \multirow[b]{2}{*}{$\mathrm{t}$} & \multirow[b]{2}{*}{ Sig. } \\
\hline & B & Std. Error & & & \\
\hline (Constant) & 42.160 & 9.956 & & 4.235 & .000 \\
\hline Academic Supervision & .241 & .090 & .270 & 2.678 & .009 \\
\hline Organizational culture & .459 & .089 & .519 & 5.140 & .000 \\
\hline
\end{tabular}


1) The Effect of Academic Supervision on Teacher Performance

The $\mathrm{t}$-count for the academic control variable is 2.678 with a tsig value based on the above-mentioned coefficient table. Table $\mathrm{dk}=\mathrm{n}-2=86-2=84$ is 1.66342 and the value is 1.66342 This is the sum of tcount (2.678)> t table (1.66342) and the value of tsig (0.009) $<\alpha(0.05)$. Academic supervision has an impact on the success of teachers in Ogan Komering Ulu County Senior High School, which can be explained.

2) The Effect of Organizational Culture on Teacher Performance

The tcount of Organizational cultures is 5,140, the tsig value is equivalent to 0.000 , while the $\mathrm{t} d \mathrm{k}$ value $=\mathrm{n}$

Table 5. Results of the Determinant Coefficient of Academic Supervision Variables $\left(\mathrm{X}_{1}\right)$ and Organizational Culture $\left(\mathrm{X}_{2}\right)$ on Teacher Performance $(\mathrm{Y})$

\section{Model Summary}

\begin{tabular}{|c|r|r|c|c|}
\hline Model & \multicolumn{1}{|c|}{$\mathrm{R}$} & R Square & $\begin{array}{c}\text { Adjusted R } \\
\text { Square }\end{array}$ & $\begin{array}{c}\text { Std. Error of } \\
\text { the Estimate }\end{array}$ \\
\hline 1 & $.727^{\mathrm{a}}$ & .529 & .517 & 7.900 \\
\hline \multicolumn{2}{|l}{$\begin{array}{l}\text { a. Predictors: (Constant), Organizational culture, } \\
\text { Academic Supervision }\end{array}$}
\end{tabular}

$-2=86-2=84$ is 1,66342 . The value of the $t \mathrm{dk}$ table is equivalent to 0.000 . That is, Ho is refused and $\mathrm{Ha}$ is accepted for the amount of $t \operatorname{count}(5.140)>t$ table(1.66342) and $\operatorname{tsig}(0.000)<\alpha(0.05)$. It can be clarified how the success of Ogan Komering Ulu District Senior High School's teachers is affected by organizational culture. More information can be found in the appendix on the effects of the t-test (partial hypothesis).

In table 5 below, the extent to which independent variable influencing the administering variable (teacher performance) can be determined (Academic Supervision and Organizational Culture).
The value of the correlation/relation (R), equal to 0.727 , is explained in table 5 . The above table indicates the value of the $\mathrm{R}^{2}$ decision coefficient of 0.529 (52.9 percent ). This indicates that the disparity in instructional and organizational management affects the difference of $52.9 \%$ in instructor results. In addition to academic monitoring and organisation, the remaining $47.1 \%$ were determined by other influences that were not discussed in this report.

\section{The Effect of Academic Supervision $\left(X_{1}\right)$ on Teacher Performance (Y)}

It is understood that Academic Supervision $\left(\mathrm{X}_{1}\right)$ has an effect on instructor success based on the study findings (Y). The Academic Supervision tcount (5.140)> t table (1.66342) and the Academic Supervision values (0.009) $<\alpha$ are evidence of this $(0.05)$. These findings reinforce the idea that academic supervision has an effect on the success of teachers. In accordance with calculation results based on a regression equation driven by Table 4.11 (coefficient), it can be explained that the teacher performance (Y) increases to 0.241 while the coefficient value of the Academic Supervision component $\left(\mathrm{X}_{1}\right)$ increases by one unit score.
A theory supports this research, states that academic supervision is an ability that is expected to maintain an effective positive relationship so that the desires of both parties are achieved. (1) the government, local authorities, school boards and school/madrasah committees shall supervise all levels of education management and education types in accordance with their respective authorities - each; (2) the supervision referred to in paragraph 1 shall be appointed to the provisions of the Law of the Republic of Indonesia, No 20 of 2004 relating the national education system Article 66 which provides; (3) And (3) the oversight requirements referred to in paragraph 1 are further governed by federal regulations. Government regulations. The teacher's level of performance success can be seen through educational supervision activities carried out by the principal using various supervision techniques.

The results are consistent with the results of this study[4]. The findings indicate that academic supervision $\mathrm{X}_{1}$, with an impact of 12.3 percent of the t-test results, of the education unit significantly influences the success of the Junior High School in Prabumulih City. The higher academic monitoring in the education unit, the better the 
teacher performance, to understand how academic supervision has an impact on teachers' performance. Research outcomes are calculated using basic regression analysis methods by the influence of variable $\mathrm{X}$ on variable $Y$. The value of the decision coefficient $(\mathrm{R}$ Square) of 0.123 is seen in the equation (12.3 percent ). The independent variable $(\mathrm{X})$, known as academic surveillance, contributes 12.3 percent to the "teacher efficiency" variable (Y) and 87.7 percent to other variables outside the variable $(\mathrm{X})$. This shows that $12.3 \%$ of teachers' instructional oversight has an impact on their execution, which could increase teaching efficiency of school directors, teachers and other parties interested in education.

Research from Mujahidin [8] that the monitoring supervision is performed in SMP Negeri Tungkal Jaya in the area of science also supports this. This is confirmed by research. The proof is that the output of teachers is growing from bad to very high. This positive relationship can mean that the more academic supervision is applied more effectively the lessons of teachers in learning practices, with the study performed by[9] showing that both research variables have a positive relationship with a value of 75,977 . A percentage of $23.3 \%$ shows the relationship between academic supervision's effect on teacher performance in learning.

Research by Hasanah [10] findings indicate that academic supervision in Cikupa is highest in the SD group, although academic supervision has a very strong impact on teacher success.

The results of researchers with previous studies, in particular in the numbers of correlations between variables of academic supervision and teacher's performance, differ although similarities between the variables of academic supervision and teacher's performance are both meaningful and positive in the research results Several tests have shown that academic supervision in schools reduces teacher efficiency. In other words, the success of the teacher will increase if instructional monitoring is carried out properly.

Based on this view, the supervision in academic institutions in the success of teachers in carrying out tasks can be said to be closely linked. Furthermore, from the results of the data on teacher performance, it shows that the performance of the SMA Negeri Ogan Komering Ulu Regency teachers in terms of quality of work, timeliness, responsibility, ability to complete work and fostering good cooperation has reached the sufficient category with the data obtained of the determination coefficient of $52.9 \%$. Teacher performance is a series of important and specific tasks that exist in the school division. Performance improvement based on research results can be done by increasing the academic supervision of educational units carried out to help teachers identify deficiencies in carrying out learning tasks in class.

\section{The Influence of Organizational Culture $\left(\mathrm{X}_{2}\right)$ on} Teacher Performance (Y)

It is understood that organic culture $\left(\mathrm{X}_{2}\right)$ has an impact on teaching success, based on the results of the study (Y). The tcount (5.140)> the table (1.66342) and the TSIG value of the Organizational Culture $(0.009)<\alpha$ are proof of this $(0.05)$. The findings support the theory that corporate culture has an effect on the success of teachers. The estimation findings based on the regression equation, based on Table 4:11 (coefficient), will justify why teacher performance (Y) is increased by 0,459 if a coefficient value of the Organizational Culture $\left(\mathrm{X}_{1}\right)$ component is increased by one unit score.

This is in line with Purba's research (2015) [9]. The test results show that school culture has an effect on teacher performance $(\mathrm{B}=0.206 ; \mathrm{p}<0.05)$. This means that the more effective teachers believe in the culture of the school in which they work, the better the efficiency of the instructor in performing his roles and duties.

This is consistent with the findings of [10] research in the SMAN 1 Canduang district of Agam concerning the impact of organizational culture on the success of teachers. The data processing results with the t-test note that the value of the t-test output variable of organic cultures is 2,871 , whereas it is 0,007 . Compared to the meaning value used in this analysis $(\alpha=0.05)$, the meaning value is obvious to be less than the meaning standard used $(0.007<.05)$. This means that the Organizational Culture variable has a positive and important impact on SMAN 1 Canduang teaching results. Thus the proposed hypothesis is accepted at the $95 \%$ confidence level.

The Effect of Academic Supervision $\left(X_{1}\right)$ and Organizational Culture $\left(\mathbf{X}_{2}\right)$ on Teacher Performance (Y)

Academic monitoring $\left(\mathrm{X}_{1}\right)$ and organic culture $\left(\mathrm{X}_{2}\right)$, based on the findings of the study, have an effect in the success of teachers (Y). The Fcount value(46.519)> Ftable (3.11) and the F-sig value $(0.000)<\alpha$ are proof of this (0.05). These findings reinforce the theory that academic monitoring and organic culture affect the success of teachers. The magnitude of the decision coefficient (Adjustment R Square) is 0.529 , which means an effect on the dependent variable (teacher performance) of independent variables (academic supervision and organizational culture) is 52.9 percent, While the remaining $47.1 \%$ of the factors affect those that have not been analyzed in this report. The study findings demonstrate that academic and organizational cultures have an important influence on the training of teachers. These findings reinforce the theory that teacher 
performance is affected by academic supervision and organizational culture.

The findings of this analysis correspond to Sukardi [11], which indicate that the equation of regression has instructional and organizational supervision over instructor performance: $\mathrm{Y}=6,769$ and $0.401 \mathrm{X}_{1}$ and $0.275 X_{2}$. The Fcount> Ftable or 137.168> 3.090 (5 per cent significance level) regression test indicates that the instructor success is influenced by academic supervision and working discipline jointly. The measure for the vector Academic Oversight was $\mathrm{t}$ counted $>$ by $\mathrm{t}$ or $4,872>1.985$ and $t$ counted $>t$ by $t$ or $8,172>1.985$ for the discipline of work was obtained (5 percent significance level). The achievements of teaching staff at Al Huda Karangpandan in MT both have a major impact. The school's success in producing graduates who can compete with other schools is one of the school's goals. Achieving this goal requires human resources with quality performance. A good culture very much determines the realization of quality performance. The school principal drives school management. The boss must have the correct approach to inspire training staff to function best. The same thing was stated by Kristiawan [12] that teachers are an important component in teaching and learning activities. The professionalism of professors relates to skills and skills for pedagogical, family, social and technical skills. Teachers must be able to acquire skilled teacher skills to increase the level of instruction during learning processes. Teachers should plan the learning experience around their skills that they wish to do more than before.

The Effect of Academic Supervision $\left(X_{1}\right)$ and Organizational Culture $\left(\mathbf{X}_{2}\right)$ on Teacher Performance (Y)

Academic monitoring $\left(\mathrm{X}_{1}\right)$ and organic culture $\left(\mathrm{X}_{2}\right)$, based on the findings of the study, have an effect in the success of teachers (Y). The F-count value shows this $(46.519)>$ table $(3.11)$ and the Fsig $(0.000)$ value $<\alpha$ (0.05). These findings reinforce the theory that academic monitoring and organic culture affect the success of teachers. The magnitude of the decision coefficient (Adjustment R Square) is 0.529, which means an effect on the dependent variable (teacher performance) of independent variables (academic supervision and organizational culture) is 52.9 percent, while the remaining $47.1 \%$ of the factors affect those that have not been analyzed in this report. The study findings demonstrate that academic and organizational cultures have an important influence on the training of teachers. These findings reinforce the theory that academic and organizational culture influence the performance of teachers.

The findings of this analysis correspond to Sukardi [11], which indicate that the equation of regression has instructional and organizational supervision over instructor performance: $\mathrm{Y}=6,769$ and $0.401 \mathrm{X}_{1}$ and $0.275 \mathrm{X}_{2}$. The Fcount $>$ Ftable or $137.168>3.090$ (5 per cent significance level) regression test indicates that the instructor success is influenced by academic supervision and working discipline jointly. The t-test for Academic Variables obtained t-count $>$ of t-table or 4,872>1,985 and $\mathrm{t}$-count $>\mathrm{t}$-table or $8,172>1,985$ for the job discipline obtained ( 5 percent significance level). Both of these variables significantly have an influence on the performance of teachers at MTs Al Huda Karangpandan. The school's success in producing graduates who can compete with other schools is one of the school's goals. To achieve this goal requires human resources with quality performance. A good culture very much determines the realization of quality performance. The school principal drives school management. As a boss, he or she must be able to function optimally for the correct technique. The same thing was stated by Kristiawan [12] that teachers are an important component in teaching and learning activities. Teacher professionals apply to pedagogical, personal, social and technical skills and know-how. During learning, teachers must be able to develop professional teacher competence to improve the quality of learning. With their competencies, teachers can design the learning process they want to carry out to be better than before.

In line with Sufiyad [13] Proves that academic oversight and leadership in the SD Negeri Jawai Selatan District together have a direct impact on teacher results. In addition, the academic monitoring program and the leadership performance of the teaching directors at the SD Negeri Jawai Selatan District will be enhanced by the teacher performance. Academic monitoring and lead management indicator data indicate an important impact on the success of teachers. This is seen by the 0.830 or $83 \%$ correlation coefficient.

Research conducted by Rintes [14] The research findings showed that the incorporation of supervisor academic oversight and the main teacher success leadership with a determining coefficient value of 0.975 or 97.5 percent had considerable effect. In this research, it was found that the principal leadership variable contributed significantly to the improvement of teacher performance compared to the academic supervision of supervisors.

Research conducted by Hardono [15], The study findings indicated that the main leadership and academic oversight have had a constructive and important impact on the success of the teachers. This demonstrates that the application of academic oversight is needed to enhance teacher efficiency. Whether schools want to boost their teachers' engagement, it is better to increase academic supervision. 
In previous studies the results of the researchers have shown that the correlation coefficient generated by previous research has a good and high category of relationship entre the academic supervision variables and organization culture, while the results of the researchers are the same. the results of previous studies described are different from those of previous students. In previous studies, however, there were correlations with researchers, including the fact that the variables of academic oversight and principal leadership together significantly and positively affect the success of teachers. This proves that you need better academic oversight and culture if you want to increase teacher efficiency. Academic and operational oversight, in other words, has an important role in optimizing the success of teachers.

The findings of the study of hypothesis tests demonstrate that the three theories were empirically evaluated. The data analyzes reveal that the academic oversight of education units and corporate culture has a direct impact on instructor success both personally and collectively. These results reinforce a thinking paradigm that shows that academic supervision is one of the variables that improve teacher performance in order to maximize teacher performance. However, the role of organizational culture in improving teacher performance is no less important.

\section{CONCLUSION}

There are three factors based on the outcome of the study, called variable of academic supervision $\left(\mathrm{X}_{1}\right)$, organizational culture $\left(\mathrm{X}_{2}\right)$ and teacher performance $(\mathrm{Y})$ at SMA Negeri Ogan Komering Ulu Regency. The data frequency distribution tends to be normal, and respondents' level of achievement is generally in the sufficient category. Three hypotheses that as empirical truth can be accepted are: 1) The academic supervision of the SMA Negeri Ogan Komering Ulu Regency influences students, thereby improving academic supervision and the success of SMA Negeri Ogan Komering Ulu Regency teachers. 2). 2). Community of SMA Negeri Ogan Komering Ulu Regency's organizations affects the success of students, therefore improved the corporate culture, the performance of SMA Negeri Ogan Komering Ulu Regency teachers. 3) Academic and organizational culture affect the success of SMA Teachers Negeri Ogan Komering Ulu Regency, which means greater academic oversight and cultural activities in schools, the better the performance in SMA Negeri Ogan Komering Ulu Regency. Academic supervision carried out by the principal is needed in learning at school, because guidance and guidance from the principal through academic supervision can affect teacher performance. Teacher performance can be improved and the achievement of educational goals can be implemented and achieved.

\section{ACKNOWLEDGMENT}

Thanks to the Education Office of South Sumatra Province for giving research permission and collecting research data, so that this research can be completed. Thank you also to the Board of Teachers and Principals of SMA Negeri 1 OKU, SMA Negeri 4 OKU and SMA Negeri 5 OKU who wanted to become research respondents.

\section{REFERENCES}

[1] Sunarsi, Y. (2019). Pengaruh gaya kepe mimpinan dan budaya organisasi terhadap kinerja karyawan pada bank btn kantor cabang Tangerang [The influence of leadership style and organizational culture on employee performance at the Tangerang branch of the Bank BTN]. Jurnal Semarak,Vol. 2, No.1.

[2] Siagian, P. S. (2016). Teori dan Praktek Kepemimpinan [Leadership Theory and Practice]. Jakarta: PT. Rineka Cipta.

[3] Asran, M. D. (2016). Pengaruh gaya kepemimpinan kepala sekolah dan budaya organisasi terhadap kinerja guru di SMA dan MA se Kota Palangka RayalThe influence of the principal's leadership style and organizational culture on the performance of teachers in SMA and MA in Palangka Raya City]. Masters thesis, IAIN Palangka Raya.

[4] Oktaviani. D. (2018). Pengaruh Supervisi Akademik Pengawas satuan Pendidikan dan Kepemimpinan Kepala Sekolah terhadap Kinerja Guru (thesis not yet published).

[5] Arifin.2018.Pengaruh Budaya Organesasi, Kepemimpinan Kepala Sekolah dan Motivasi terhadap Kinerja Tenaga Pendidik di SMPN 2 Paciran [The Effect of Academic Supervision of Education Unit Supervisor and Principal Leadership on Teacher Performance]. (thesis not yet published).

[6] Yusuf. (2018). Pengaruh supervisi akademik kepala sekolah dan budaya organisasi terhadap kinerja mengajar guru di sekolah dasar negeri kecamatan cibadak [The effect of the principal's academic supervision and organizational culture on the teaching performance of teachers in public elementary schools in Cibadak sub-district]. S2 thesis, Universitas Pendidikan Indonesia.

[7] Sugiono. (2007). Metode Penelitian Kuantitatif Kualitatif Dan R\&D [Qualitative and Quantitative Research Methods $R \& D$ ] Bandung: Alfabeta 
[8] Mujahidin, M. (2017). Pengaruh Supervisi Akademik Pengawas Sekolah Terhadap Kinerja Guru Mata Pelajaran IPA di SMPN Tungkal Jaya [The Effect of Academic Supervision of School Supervisors on the Performance of Teachers in Science Subjects at SMPN Tungkal Jaya]. Biota, 10 (1), 35-54.

[9] Purbasari, M. (2015). Pengaruh Supervisi Akademik Terhadap Kinerja Mengajar Guru Di Sekolah Dasar [The Effect of Academic Supervision on Teacher Teaching Performance in Elementary Schools]. Journal of Elementary Education, 4(1), 46-52.

[10] Hasanah, U. U. (2015). Pengaruh Supervisi Akademik Kepala Sekolah dan Kegiatan Kelompok Kerja Guru Terhadap Kinerja Mengajar Guru di SD Negeri Se-Kecamatan Cikupa-Kabupaten Tangerang (Doctoral dissertation [The Effect of Principal Academic Supervision and Teacher Working Group Activities on Teacher Teaching Performance in Public Elementary Schools in Cikupa District, Tangerang Regency (Doctoral dissertation)], Universitas Pendidikan Indonesia).

[11] Sukardi, P. D. (2016). Metodologi Penelitian Pendidikan [Educational Research Methodology]. Jakarta: Bumi Aksara.

[12] Kristiawan, M dkk. (2018). Manajemen Pendidikan [Education Management]. Yogyakarta: Deepublish.

[13] Sufiyad, U. (2017). Pengaruh supervisi akademik dan kepemimpinan kepala sekolah terhadap kinerja guru di SD [The effect of academic supervision and principal leadership on teacher performance in elementary schools]. Jurnal Pendidikan dan Pembelajaran Khatulistiwa (JPPK), Vol 6, No 8.

[14] Rintes, M. (2016) Pengaruh Pelaksanaan Supervisi Akdemik Pengawas Sekolah Dan Kepemimpinan Kepala Sekolah Terhadap Kinerja Guru Di Sma Negeri Kabupaten Kolaka Timur [The Effect of School Supervision Academic Supervision and Principal Leadership on Teacher Performance at State Senior High Schools, East Kolaka Regency]. (thesis, Universitas Negeri Makasar).

[15] Hardono, H., Haryono, H., \& Yusuf, A. (2017). Kepemimpinan Kepala Sekolah, Supervisi Akademik, dan Motivasi Kerja dalam Meningkatkan Kinerja Guru [Principal Leadership, Academic Supervision, and Work Motivation in Improving Teacher Performance]. Educational Management, 6(1), 26-33. 